\title{
Bensingtonia changbaiensis sp. nov. and Bensingtonia sorbi sp. nov., novel ballistoconidium-forming yeast species from plant leaves
}

Correspondence

Feng-Yan Bai

baify@sun.im.ac.cn

\author{
Qi-Ming Wang, Feng-Yan Bai, Jian-Hua Zhao and Jian-Hua Jia
}

Systematic Mycology and Lichenology Laboratory, Institute of Microbiology, The Chinese Academy of Sciences, Beijing 100080, China

\begin{abstract}
Six ballistoconidium-forming yeast strains that were isolated from plant leaves collected on Changbai Mountain, north-east China, were assigned to the genus Bensingtonia Ingold emend. Nakase \& Boekhout due to the formation of asymmetrical ballistoconidia, cream-coloured colonies and $\mathrm{Q}-9$ as the major ubiquinone. Two separate groups, representing two novel Bensingtonia species, were recognized among these yeasts by 26S rDNA D1/D2 domain, internal transcribed spacer (ITS) region and $18 \mathrm{~S}$ rDNA sequence analyses. The names Bensingtonia changbaiensis sp. nov. (type strain, CB $346^{\top}=A S 2.2310^{\top}=\mathrm{CBS} 9497^{\top}$ ) and Bensingtonia sorbi sp. nov. (type strain, CB $286^{\top}=A S 2.2303^{\top}=$ CBS $9498^{\top}$ ) are proposed for these two species.
\end{abstract}

In a survey of ballistoconidium-forming yeast diversity of the phyllosphere in north-east China, approximately 250 yeast strains were isolated from 39 leaf samples of various plants collected on Changbai Mountain, Jilin Province, north-east China. Among the yeasts, six strains were classified into one group by conventional and chemotaxonomic characterization. Molecular phylogenetic analyses based on the large-subunit (26S) rDNA D1/D2 domain, the internal transcribed spacer (ITS) region and the small-subunit (18S) rDNA indicated that these strains represent two undescribed species in the genus Bensingtonia Ingold emend. Nakase \& Boekhout [see Nakase \& Boekhout (1988)]. They are hereby described as Bensingtonia changbaiensis sp. nov. and Bensingtonia sorbi sp. nov.

The six strains studied were isolated from wilting leaves of Aconitum coreanum (CB 228), Betula ermanii (CB 255 and CB $346^{\mathrm{T}}$ ) and Sorbus pohuashanensis (CB 284, CB $286^{\mathrm{T}}$ and $\mathrm{CB} 287$ ) by using the improved ballistoconidia-fall method (Nakase \& Takashima, 1993). Leaf samples were collected on Changbai Mountain in October 1998. Morphological, physiological and biochemical characteristics were

Published online ahead of print on 6 June 2003 as DOI 10.1099/ ijs.0.02736-0.

Abbreviation: ITS, internal transcribed spacer.

The GenBank/EMBL/DDBJ accession numbers for the $18 \mathrm{~S}$ rDNA, internal transcribed spacer (ITS) region and 26S rDNA D1/D2 domain sequences determined in this study are AY233339-AY233345.

Phylogenetic trees based on ITS and 18S rDNA sequences are available as supplementary data in IJSEM Online. examined according to standard methods (Yarrow, 1998). Extraction, purification and identification of ubiquinones were carried out according to Yamada \& Kondo (1973). Assimilation of nitrogen compounds was investigated on solid media with starved inocula (Nakase \& Suzuki, 1986).

Nuclear DNA was extracted by the method of Makimura et al. (1994). The ITS (including 5.8S rDNA) and $26 \mathrm{~S} \mathrm{rDNA}$ D1/D2 domain sequences were determined by a method described previously (Bai et al., 2002). 18S rDNA sequences were determined according to Sugita \& Nakase (1999) with the following modifications: cycle sequencing was performed by using an ABI BigDye Cycle Sequencing kit and electrophoresis and data collection were performed on an ABI PRISM 3100 genetic analyser. Sequences were aligned with the CLUSTAL_X program (Thompson et al., 1997). Phylogenetic trees were constructed from evolutionary distance data calculated with Kimura's two-parameter model (Kimura, 1980) by using the neighbour-joining method (Saitou \& Nei, 1987). Bootstrap analysis (Felsenstein, 1985) was performed from 1000 random resamplings.

\section{Morphology and chemotaxonomy}

The six yeast strains (CB 228, CB 255, CB 284, CB $286^{\mathrm{T}}$, CB 287 and CB $346^{\mathrm{T}}$ ) were classified together by their formation of asymmetrical ballistoconidia and cream-coloured colonies. Their major ubiquinone was Q-9. Sexual structures were not observed in cultures of single strains or in mating tests. According to the current taxonomy of basidiomycetous yeasts (Boekhout, 1998; Boekhout \& Nakase, 1998), these strains could be assigned to the genus Bensingtonia. 


\section{Molecular phylogenetic analysis}

Two groups were recognized among the six strains by ITS and D1/D2 sequence comparison. Strains CB $286^{\mathrm{T}}$ and CB 287 had identical sequences in both regions. CB 228, CB 255, CB 284 and CB $346^{\mathrm{T}}$ were classified into another group that also had identical sequences in both regions except for $\mathrm{CB}$ 284, which differed from the other three strains by $1 \mathrm{nt}$ in the D1/D2 region. The two groups differed from each other by $34 \mathrm{nt}(5 \%)$ in the D1/D2 region and $143 \mathrm{nt}(\sim 25 \%)$ in the ITS $-5 \cdot 8 \mathrm{~S}$ rDNA region.

In the phylogenetic tree drawn from D1/D2 sequences (Fig. 1), the two groups were located in the Kondoa clade, Agaricostilbum lineage of urediniomycetous yeasts (Scorzetti et al., 2002). They clustered together with Bensingtonia yuccicola and an undescribed Bensingtonia species represented by strain PYCC 5562 (Fig. 1). The Changbai strains differed from the latter two taxa by approximately $3-4 \%$ of nucleotides in the D1/D2 region. More than $20 \%$ nucleotide difference was found in the ITS region among closely related Bensingtonia taxa.

Phylogenetic positions of the two groups depicted in the D1/D2 tree (Fig. 1) were different from those depicted in the ITS tree. Such discordances have been reported in other groups of basidiomycetous yeasts (Bai et al., 2002; Scorzetti et al., 2002). In order to confirm the phylogenetic positions of the two groups, $18 \mathrm{~S}$ rDNA sequences of the representative strains CB $286^{\mathrm{T}}$ and CB $346^{\mathrm{T}}$ were determined and aligned with those of reference taxa, including all described Bensingtonia species and related urediniomycetous yeast taxa. The two strains clustered together with five Bensingtonia and one Kondoa species in the Agaricostilbum/Bensingtonia lineage (Hamamoto \& Nakase, 2000) with $100 \%$ bootstrap support. CB $286^{\mathrm{T}}$ was located with Bensingtonia miscanthi, whereas $\mathrm{CB} 346^{\mathrm{T}}$ showed a close relationship to B. yuccicola.
The ITS and $18 \mathrm{~S}$ rDNA trees are available as supplementary data in IJSEM Online.

The results suggest that the two yeast groups from Changbai Mountain represent two novel Bensingtonia species, for which the names Bensingtonia changbaiensis sp. nov. and Bensingtonia sorbi sp. nov. are proposed.

\section{Latin diagnosis of Bensingtonia changbaiensis F.-Y. Bai et Q.-M. Wang sp. nov.}

In YM (Difco) liquido post dies 5 ad $17^{\circ} \mathrm{C}$, cellulae vegetativae ellipsoideae, $2 \cdot 0-3 \cdot 6 \times 4 \cdot 5-8 \cdot 6 \mu \mathrm{m}$, singulae. Sedimentum formantur. Post unum mensem ad $17^{\circ} \mathrm{C}$, annulus et sedimentum formantur. In agaro YM post unum mensem ad $17^{\circ} \mathrm{C}$, cultura brunneusa-cremea, glabra aut rugosa, nitida aut non-nitida, butyracea, margine glabra. Pseudomycelium non formantur. Ballistosporae reniformia vel allantoidia, $2 \cdot 7-4 \cdot 1 \times 5 \cdot 6-10 \cdot 9 \mu \mathrm{m}$. Fermentatio nulla. Glucosum, saccharosum, maltosum, cellobiosum (lente), trehalosum, raffinosum (lente), inulinum (lente et exigue), amylum solubile (lente), D-xylosum (lente et exigue), glycerolum, ribitolum (lente et exigue), D-mannitolum et D-glucitolum (lente) assimilantur at non galactosum, L-sorbosum, lactosum, melibiosum, melezitosum, L-arabinosum, D-arabinosum, D-ribosum, L-rhamnosum, D-glucosaminum, methanolum, ethanolum, erithritolum, galactitolum, methyl- $\alpha-\mathrm{D}-$ glucosidum, salicinum, acidum DL-lacticum, acidum succinicum, acidum citricum, inositolum nec hexadecanum. Ammonium sulfatum, kalium nitricum, natrum nitrosum et $\mathrm{L}-\mathrm{lysinum}$ assimilantur at non ethylaminum nec cadaverinum. Vitaminae externae ad crescentiam necessaria sunt. Maxima temperatura crescentiae: $27^{\circ} \mathrm{C}$. Materia amyloidea iodophila non formantur. Urea finditur. Diazonium caeruleum B positivum. Ubiquinonum majus: Q-9.

Typus: isolatus ex folio Betula ermanii, CB $346^{\mathrm{T}}$, depositus in

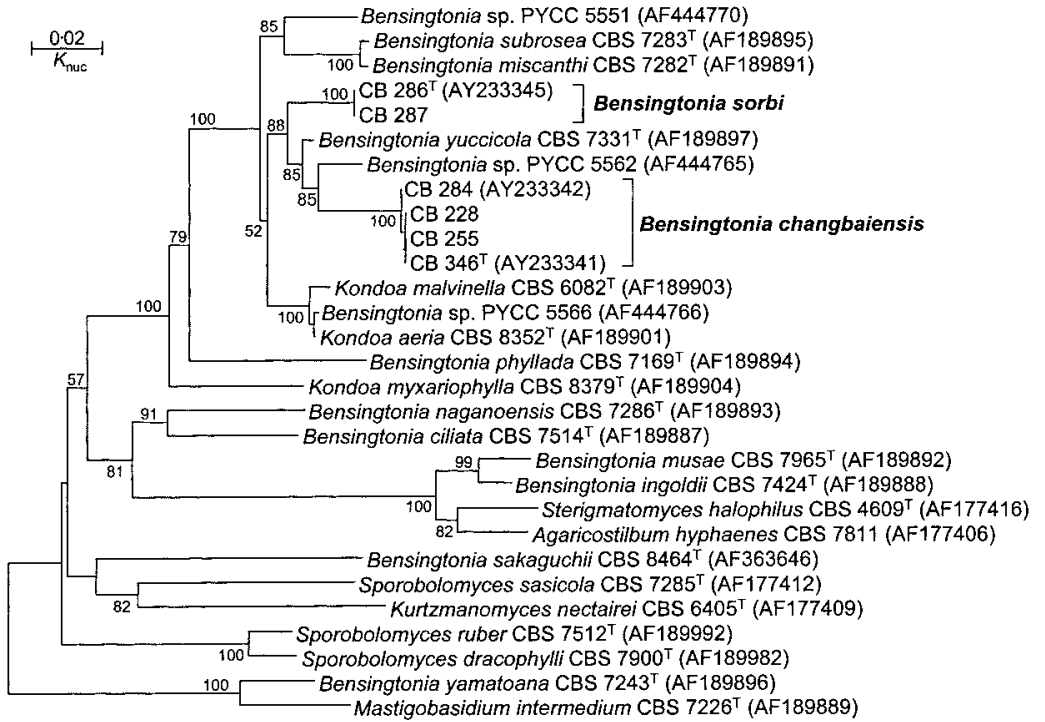

Fig. 1. Phylogenetic tree drawn from neighbour-joining analysis of 26S rDNA D1/ D2 domain sequences, depicting relationships of the Bensingtonia strains from northeast China with closely related taxa. Bootstrap percentages $>50 \%$ from 1000 bootstrap replicates are shown. Reference sequences were retrieved from GenBank under the accession numbers indicated. 
collectione China General Microbiological Culture Collection Center, Academia Sinica (AS 2.2310 ${ }^{\mathrm{T}}$ ).

\section{Description of Bensingtonia changbaiensis F.-Y. Bai \& Q.-M. Wang sp. nov.}

Bensingtonia changbaiensis (chang.bai.en'sis. N.L. fem. adj. changbaiensis referring to the geographical origin of the type strain of the species).

In YM broth after 5 days at $17^{\circ} \mathrm{C}$, cells are ellipsoidal, $2 \cdot 0-3 \cdot 6 \times 4 \cdot 5-8 \cdot 6 \mu \mathrm{m}$ (Fig. 2), single, budding is polar and sediment is formed. After 1 month at $17^{\circ} \mathrm{C}$, sediment and a ring are present. On YM agar after 1 month at $17^{\circ} \mathrm{C}$, the streak culture is brownish-cream, butyrous, smooth or slightly wrinkled and shining or dull. The margin is entire. In Dalmau plate culture on corn-meal agar, pseudohyphae are not formed. Ballistoconidia are produced on sterigmata of 5-12 $\mu \mathrm{m}$ long; they are ellipsoidal, reniform or allantoid and $2 \cdot 7-4 \cdot 1 \times 5 \cdot 6-10 \cdot 9 \mu \mathrm{m}$ (Fig. 2). Fermentation is negative.
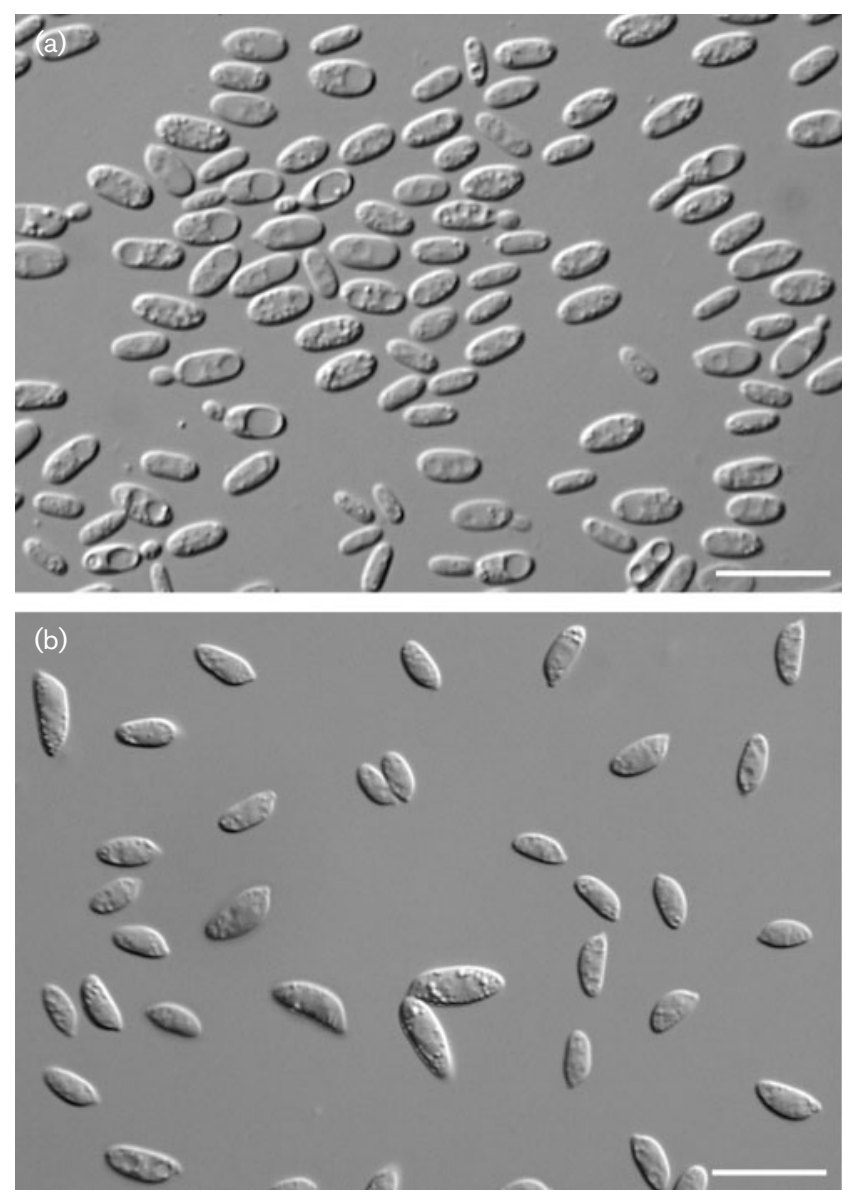

Fig. 2. Bensingtonia changbaiensis sp. nov. CB $346^{\top}$ vegetative cells grown in YM broth for 5 days at $17^{\circ} \mathrm{C}$ (a) and ballistoconidia produced on corn-meal agar after 5 days at $20^{\circ} \mathrm{C}$ (b). Bars, $10 \mu \mathrm{m}$.
Glucose, sucrose, maltose, cellobiose (delayed), trehalose, raffinose (delayed), inulin (delayed and weak), soluble starch (delayed), D-xylose (delayed and weak), glycerol, ribitol (delayed and weak), D-mannitol and D-glucitol (delayed) are assimilated. Galactose, L-sorbose, lactose, melibiose, melezitose, L-arabinose, D-arabinose, D-ribose, L-rhamnose, D-glucosamine, methanol, ethanol, erythritol, galactitol, methyl $\alpha$-D-glucoside, salicin, DL-lactic acid, succinic acid, citric acid, inositol and hexadecane are not assimilated. Ammonium sulfate, potassium nitrate, sodium nitrite and L-lysine are assimilated. Ethylamine hydrochloride and cadaverine dihydrochloride are not assimilated. Maximum growth temperature is $27^{\circ} \mathrm{C}$. Growth in vitamin-free medium is negative. Starch-like substances are not produced. Growth on $50 \%(w / w)$ glucose-yeast extract agar is negative. Urease activity is positive. Diazonium blue $\mathrm{B}$ reaction is positive. Major ubiquinone is Q-9.

The type strain of Bensingtonia changbaiensis, CB $346^{\mathrm{T}}$, was isolated from a wilting leaf of Betula ermanii Cham collected on Changbai Mountain, north-east China, in October 1998. This strain has been deposited in the China General Microbiological Culture Collection Center (CGMCC), Academia Sinica, Beijing, China, as AS $2.2310^{\mathrm{T}}$ $\left(=\right.$ CBS $\left.9497^{\mathrm{T}}\right)$.

\section{Latin diagnosis of Bensingtonia sorbi F.-Y. Bai et Q.-M. Wang sp. nov.}

In $\mathrm{YM}$ (Difco) liquido post dies 5 ad $17^{\circ} \mathrm{C}$, cellulae vegetativae ovoideae et globosa, 2.7-6.4 $\times 2 \cdot 7-8 \cdot 6 \mu \mathrm{m}$, singulae. Annulus et sedimentum formantur. Post unum mensem ad $17^{\circ} \mathrm{C}$, annulus et sedimentum formantur. In agaro YM post unum mensem ad $17^{\circ} \mathrm{C}$, cultura brunneusa-cremea, glabra aut rugosa, nitida aut non-nitida, butyracea, margine glabra. Pseudomycelium non formantur. Ballistosporae ovoideae, $2 \cdot 7-$ $4 \cdot 5 \times 4 \cdot 1-7 \cdot 3 \mu \mathrm{m}$. Fermentatio nulla. Glucosum, L-sorbosum, galactosum (lente), saccharosum, maltosum, trehalosum, raffinosum, D-xylosum, L-arabinosum (lente et exigue), glycerolum, ribitolum (lente et exigue), D-mannitolum et D-glucitolum assimilantur at non cellobiosum, lactosum, melibiosum, melezitosum, inulinum, amylum solubile, Darabinosum, D-ribosum, L-rhamnosum, D-glucosaminum, methanolum, ethanolum, erithritolum, galactitolum, methyl$\alpha$-D-glucosidum, salicinum, acidum DL-lacticum, acidum succinicum, acidum citricum, inositolum nec hexadecanum. Ammonium sulfatum, L-lysinum et cadaverinum assimilantur at non kalium nitricum, natrum nitrosum nec ethylaminum assimilantur. Vitaminae externae ad crescentiam necessaria sunt. Maxima temperatura crescentiae: $27^{\circ} \mathrm{C}$. Materia amyloidea iodophila non formantur. Urea finditur. Diazonium caeruleum B positivum. Ubiquinonum majus: Q-9.

Typus: isolatus ex folio Sorbus pohuashanensis, CB $286^{\mathrm{T}}$, depositus in collectione China General Microbiological Culture Collection Center, Academia Sinica (AS 2.2303 ${ }^{\mathrm{T}}$ ). 


\section{Description of Bensingtonia sorbi F.-Y. Bai \& Q.-M. Wang sp. nov.}

Bensingtonia sorbi (sor'bi. N.L. gen. adj. sorbi of Sorbus, referring to the genus name of the plant from which the type strain was isolated).

In YM broth after 5 days at $17^{\circ} \mathrm{C}$, cells are ovoidal or globose, $2 \cdot 7-6 \cdot 4 \times 2 \cdot 7-8 \cdot 6 \mu \mathrm{m}$ (Fig. 3), single, budding is polar, sediment and a ring are formed. After 1 month at $17^{\circ} \mathrm{C}$, sediment and a ring are present. On YM agar after 1 month at $17^{\circ} \mathrm{C}$, the streak culture is brownish-cream, butyrous, smooth or slightly wrinkled and shining or semidull. The margin is entire. In Dalmau plate culture on cornmeal agar, pseudohyphae are not formed. Ballistoconidia are produced on corn-meal agar, ovoidal, $2 \cdot 7-4.5 \times$ $4 \cdot 1-7 \cdot 3 \mu \mathrm{m}$ (Fig. 3). Fermentation is negative. Glucose, Lsorbose, galactose (delayed), sucrose, maltose, trehalose, raffinose, D-xylose, L-arabinose (delayed and weak), glycerol, ribitol (delayed and weak), D-mannitol and D-glucitol are assimilated. Cellobiose, lactose, melibiose, melezitose,
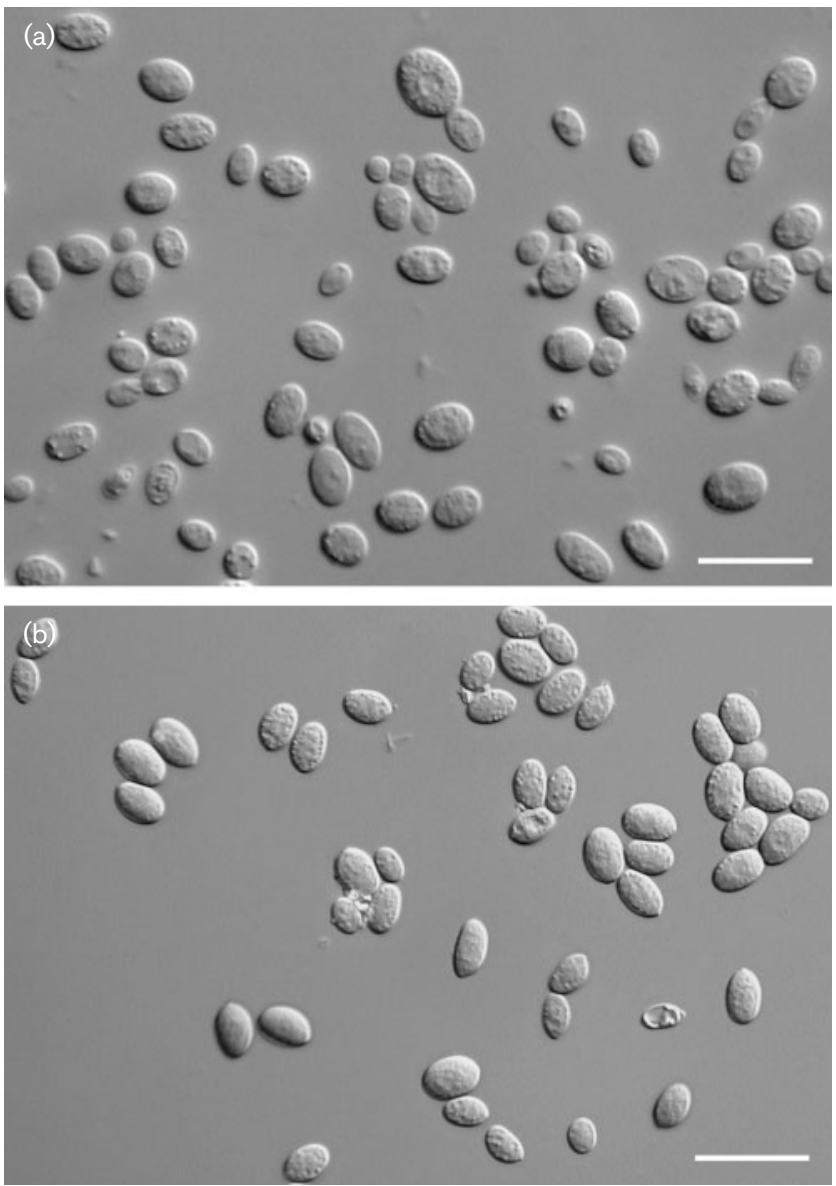

Fig. 3. Bensingtonia sorbi sp. nov. CB $286^{\top}$ vegetative cells grown in $\mathrm{YM}$ broth for 5 days at $17^{\circ} \mathrm{C}$ (a) and ballistoconidia produced on corn-meal agar after 5 days at $20^{\circ} \mathrm{C}$ (b). Bars, $10 \mu \mathrm{m}$. inulin, soluble starch, D-arabinose, D-ribose, L-rhamnose, D-glucosamine, methanol, ethanol, erythritol, galactitol, methyl $\alpha$-D-glucoside, salicin, DL-lactic acid, succinic acid, citric acid, inositol and hexadecane are not assimilated. Ammonium sulfate, L-lysine and cadaverine dihydrochloride are assimilated. Potassium nitrate, sodium nitrite and ethylamine hydrochloride are not assimilated. Maximum growth temperature is $27^{\circ} \mathrm{C}$. Growth in vitamin-free medium is negative. Starch-like substances are not produced. Growth on $50 \%$ (w/w) glucose-yeast extract agar is negative. Urease activity is positive. Diazonium blue $\mathrm{B}$ reaction is positive. Major ubiquinone is Q-9.

The type strain of Bensingtonia sorbi, CB $286^{\mathrm{T}}$, was isolated from a wilting leaf of Sorbus pohuashanensis (Hance) Hedl collected on Changbai Mountain, north-east China, in October 1998. This strain has been deposited in the China General Microbiological Culture Collection Center (CGMCC), Academia Sinica, Beijing, China, as AS $2.2303^{\mathrm{T}}$ $\left(=\mathrm{CBS} 9498^{\mathrm{T}}\right)$.

In addition to differences in molecular data, the two novel Bensingtonia species are distinguishable from each other and from other described species of the genus by some physiological properties, as shown in Table 1. With the inclusion of the recently described species Bensingtonia thailandica Fungsin et al. (2001) and the anamorph of Mastigobasidium intermedium Golubev (1999) (Bensingtonia intermedia), 14 species are now included in the genus Bensingtonia (Table 1). Although the heterogeneity of this genus, as well as a number of other basidiomycetous yeast

Table 1. Physiological characteristics that differentiate $B$. changbaiensis and B. sorbi from described species

Species: 1 , B. changbaiensis; 2, B. sorbi; 3, Bensingtonia ciliata; 4, Bensingtonia ingoldii; 5, Bensingtonia intermidia; 6, B. miscanthi; 7, Bensingtonia musae; 8, Bensingtonia naganoensis; 9, Bensingtonia phyllada; 10, Bensingtonia sakaguchii; 11, Bensingtonia subrosea; 12, B. thailandica; 13, Bensingtonia yamatoana; 14, B. yuccicola. Abbreviations: + , positive; L, delayed positive; $\mathrm{W}$, weakly positive; $\mathrm{S}$, slow positive; -, negative; $\mathrm{V}$, variable.

\begin{tabular}{|c|c|c|c|c|c|c|c|c|c|c|c|c|}
\hline Characteristic & 1 & 2 & 3 & 4 & 5 & 6 & 7 & 8 & 9 & 1011 & 1213 & 14 \\
\hline \multicolumn{13}{|l|}{ Assimilation of: } \\
\hline L-Sorbose & - & + & $\mathrm{W}$ & - & + & $\mathrm{L}$ & + & - & + & $-\mathrm{L}$ & -- & + \\
\hline Sucrose & + & + & - & + & $\mathrm{V}$ & + & - & + & + & -+ & ++ & - \\
\hline Maltose & + & + & - & - & $\mathrm{V}$ & - & - & + & + & ++ & ++ & - \\
\hline Cellobiose & $\mathrm{L}$ & - & - & + & + & + & - & + & + & ++ & +- & + \\
\hline Trehalose & + & + & + & + & + & + & + & - & + & ++ & ++ & + \\
\hline Lactose & - & - & - & + & - & $\mathrm{L}$ & - & - & $\mathrm{w}$ & ++ & -- & - \\
\hline Melibiose & - & - & - & + & - & - & - & + & - & -- & +- & - \\
\hline Raffinose & $\mathrm{L}$ & + & - & $\mathrm{L}$ & - & $\mathrm{L}$ & - & + & - & -+ & +- & - \\
\hline Soluble starch & $\mathrm{L}$ & - & - & $\mathrm{s}$ & - & - & - & + & + & ++ & $+\mathrm{V}$ & - \\
\hline D-Xylose & $-(\mathrm{w})$ & + & - & + & $\mathrm{V}$ & $\mathrm{L}$ & + & - & - & $-\mathrm{L}$ & $-\mathrm{L}$ & - \\
\hline L-Arabinose & - & - & - & + & & - & $\mathrm{L}$ & - & $\mathrm{W}$ & -- & -- & - \\
\hline Nitrate & $\mathrm{L}$ & - & + & + & - & + & - & + & + & -- & +- & + \\
\hline
\end{tabular}


genera, has been demonstrated by rRNA gene sequence analyses (Takashima et al., 1995; Fell et al., 2000; Hamamoto \& Nakase, 2000; Scorzetti et al., 2002), redefinitions of these genera would be premature at present. Relationships among lineages and clades of these yeasts should become clearer as novel species are added to the phylogenetic trees, which is hoped to make the demarcation of genera more reliable.

\section{Acknowledgements}

This study was supported by grants no. 30170002 from the National Natural Science Foundation of China (NSFC) and no. KSCX2-SW101C from the Chinese Academy of Sciences.

\section{References}

Bai, F.-Y., Zhao, J.-H., Takashima, M., Jia, J.-H., Boekhout, T. \& Nakase, T. (2002). Reclassification of the Sporobolomyces roseus and Sporidiobolus pararoseus complexes, with the description of Sporobolomyces phaffii sp. nov. Int J Syst Evol Microbiol 52, 2309-2314.

Boekhout, T. (1998). Diagnostic descriptions and key to presently accepted heterobasidiomycetous genera. In The Yeasts, a Taxonomic Study, 4th edn, pp. 627-634. Edited by C. P. Kurtzman \& J. W. Fell. Amsterdam: Elsevier.

Boekhout, T. \& Nakase, T. (1998). Bensingtonia Ingold emend. Nakase \& Boekhout. In The Yeasts, a Taxonomic Study, 4th edn, pp. 723-730. Edited by C. P. Kurtzman \& J. W. Fell. Amsterdam: Elsevier.

Fell, J. W., Boekhout, T., Fonseca, A., Scorzetti, G. \& StatzellTallman, A. (2000). Biodiversity and systematics of basidiomycetous yeasts as determined by large-subunit rDNA D1/D2 domain sequence analysis. Int J Syst Evol Microbiol 50, 1351-1371.

Felsenstein, J. (1985). Confidence limits on phylogenies: an approach using the bootstrap. Evolution 39, 783-791.

Fungsin, B., Hamamoto, M., Arunpairojana, V., Sukhumavasi, J., Atthasampunna, P. \& Nakase, T. (2001). Bensingtonia thailandica sp. nov., a novel basidiomycetous yeast species isolated from plant leaves in Thailand. Int J Syst Evol Microbiol 51, 1209-1213.

Golubev, W. I. (1999). Mastigobasidium, a new teleomorphic genus for the perfect state of ballistosporous yeast Bensingtonia intermedia. Int J Syst Bacteriol 49, 1301-1305.
Hamamoto, M. \& Nakase, T. (2000). Phylogenetic analysis of the ballistoconidium-forming yeast genus Sporobolomyces based on 18 rDNA sequences. Int J Syst Evol Microbiol 50, 1373-1380.

Kimura, M. (1980). A simple method for estimating evolutionary rates of base substitutions through comparative studies of nucleotide sequences. J Mol Evol 16, 111-120.

Makimura, K., Murayama, S. Y. \& Yamaguchi, H. (1994). Detection of a wide range of medically important fungi by the polymerase chain reaction. J Med Microbiol 40, 358-364.

Nakase, T. \& Boekhout, T. (1988). Emendation of the genus Bensingtonia Ingold. J Gen Appl Microbiol 34, 433-437.

Nakase, T. \& Suzuki, M. (1986). Bullera megalospora, a new species of yeast forming large ballistospores isolated from dead leaves of Oryza sativa, Miscanthus sinensis and Sasa sp. in Japan. J Gen Appl Microbiol 32, 225-240.

Nakase, T. \& Takashima, M. (1993). A simple procedure for the high frequency isolation of new taxa of ballistosporous yeasts living on the surfaces of plants. RIKEN Rev 3, 33-34.

Saitou, N. \& Nei, M. (1987). The neighbor-joining method: a new method for reconstructing phylogenetic trees. Mol Biol Evol 4, 406-425.

Scorzetti, G., Fell, J. W., Fonseca, A. \& Statzell-Tallman, A. (2002). Systematics of basidiomycetous yeasts: a comparison of large subunit D1/D2 and internal transcribed spacer rDNA regions. FEMS Yeast Res 2, 495-517.

Sugita, T. \& Nakase, T. (1999). Non-universal usage of the leucine CUG codon and the molecular phylogeny of the genus Candida. Syst Appl Microbiol 22, 79-86.

Takashima, M., Suh, S.-O. \& Nakase, T. (1995). Phylogenetic relationships among species of the genus Bensingtonia and related taxa based on the small subunit ribosomal DNA sequences. J Gen Appl Microbiol 41, 131-141.

Thompson, J. D., Gibson, T. J., Plewniak, F., Jeanmougin, F. \& Higgins, D. G. (1997). The CLUSTAL_X windows interface: flexible strategies for multiple sequence alignment aided by quality analysis tools. Nucleic Acids Res 25, 4876-4882.

Yamada, Y. \& Kondo, K. (1973). Coenzyme Q system in the classification of the yeast genera Rhodotorula and Cryptococcus and the yeast-like genera Sporobolomyces and Rhodosporidium. J Gen Appl Microbiol 19, 59-77.

Yarrow, D. (1998). Methods for the isolation, maintenance and identification of yeasts. In The Yeasts, a Taxonomic Study, 4th edn, pp. 77-100. Edited by C. P. Kurtzman \& J. W. Fell. Amsterdam: Elsevier. 